\title{
Suitability of the Natural Resources of Reusam Aceh Jaya Island to Become an Ecotourism Area
}

\author{
Izwar $^{1}$, Badaruddin $^{2}$, Miswar Budi Mulya ${ }^{3}$, Robert Sibarani ${ }^{4}$ \\ \{badaruddin.usu@gmail.com ${ }^{2}$ \}
}

\begin{abstract}
Natural Resource Management and Environment, Universitas Sumatera Utara, Indonesia ${ }^{1}$
Universitas Sumatera Utara, Medan, Indonesia ${ }^{2,3,4}$
\end{abstract}

\begin{abstract}
Ecotourism is a type of tourism that supports conservation and gives appreciation to the environment, social culture and community participation. The management of the ecotourism area on Reusam Island is very much needed to find out the potential and constraints obtained by visitors in the sustainable development of the ecotourism area. This research was conducted in August 2018 until July 2019, carried out by direct observation to collect primary data following expert provisions. Conformity analysis is done to get the suitability of field conditions with the ideal conditions of experts. Based on the topography, Reusam Island is included in the very small island category, an area of about 22 hectares, which is divided into 4 regions. Reusam Island resources are based on water geomorphological parameters, diversity, marine oceanography physics, water quality, and supporting factors following the indicators of the suitability of experts to become ecotourism areas.
\end{abstract}

Keywords: Ecotourism, Natural Resource, Reusam Island, Aceh Jaya

\section{Introduction}

Ecotourism was first coined by Hector Ceballos-Lascurain in 1987, namely: Nature tourism or ecological tourism by traveling to natural places that are relatively undisturbed or contaminated (contaminated) with the aim to study, admire and enjoy the scenery, plants, and animals wild, and forms of cultural manifestations of society that exist, both from the past and the present [24]. Then in the early 1990s, it was perfected by The International Ecotourism Society (TIES), as follows: Ecotourism is a responsible journey to natural places by preserving the environment and improving the welfare of residents [24]. Understanding ecotourism from time to time experiencing development. But essentially the notion of ecotourism is a form of tourism that is responsible for the preservation of unspoiled areas, providing economic benefits and maintaining cultural integrity for the local community [37].

The coastal area is a strategic area that determines the quality of the land, this is because the coastal area has a free relationship with the open sea and receives freshwater input from the mainland. In addition to the beauty of the beach, the coastal region also has resources that are not owned by other regions, in the complex coastal areas there will be found three main ecosystems 
mutually support the existence of these three ecosystems. Mangrove, seagrass and coral reef ecosystems. Mangrove ecosystems on land function as a filter for nutrients and sedimentation from the mainland to improve water quality before reaching seagrass beds. While seagrass ecosystems that lie between mangrove ecosystems and coral reefs function as filters for nutrients and sedimentation before burdening coral reefs (improving water quality). At the same time, the coral reef ecosystem acts as a buffer to break the wave power before reaching the seagrass beds and mangrove stands to protect the integrity of the coast.

Meanwhile, according to Adrianto [2], in the perspective of ecosystems in coastal areas, the area of small islands can be divided into several sub-regions, namely: (1) coastal offshore zones; beach area (beach zone); (3) coastal lowland zone; (4) inland zone (inland zone). Judging from the complexity and beauty of the coastal area, it makes it an ecotourism area that is often visited, both as tourists and researchers.

The potential and opportunities of coastal areas and small islands to become ecotourism areas are very large. With the existence of tourism activities will provide additional income for both the region and the people in the area. Besides the positive benefits, making the coastal area into an ecotourism area also has a negative impact, especially if there is no sense of belonging that our shared environment and must be taken care of together, both visitors and local communities who depend their lives on these tourism activities.

The most common pollution we encounter in tourist areas includes physical, biological and impacts on wildlife including animal disturbance and feeding. Other impacts include littering, collections of artifacts, graffiti and damage to coral reefs (Farrell \& Marion, 2001). Environmental damage will continue if the management of tourist areas without an environmental basis (ecotourism), for example, environmental degradation that occurred in Honduras found by Stonich in Zambrano et.al [38] found that tourism in Honduras caused significant environmental degradation which affects the health of the local population. Besides, the sustainability of ecotourism can be questioned and disrupted if destiny requires a long journey, as a result, it will have a global impact because of the farther away from the ecotourism destination, the more fossil energy needed by Marzouki et. al [18]. Efforts to anticipate degradation is by requiring the island and coastal areas which are encapsulated by ecotourism areas should get the attention of all parties, especially in development and management.

Baksir [3] explains the understanding of small island management is a process of planning, utilization, supervision, and control of small island resources whose area $=2,000 \mathrm{~km} 2$, functionally interacting from the ecological, economic, socio-cultural aspects, both individually and synergistically can improve the welfare of the community. With professional management, where a portion of the income from tourism activities is used to conserve the ecosystems in the region, it can continue to protect and maintain the beauty and attractiveness of tourists. So that it can help the achievement of the Indonesian government's targets through the ministry of tourism have six main targets for the 2014-2019 period: (1) tourism's contribution to Gross Domestic Product (GDP) increased from 9 percent in 2014 to 15 percent in 2019. As of November 2015, tourism's contribution to GDP was 9.5 percent, (2) foreign exchange increased from IDR 140 trillion in 2014 to IDR 280 trillion in 2019. Currently the contribution of tourism to the National GDP is estimated to reach 4 percent with foreign exchange of IDR 155 trillion, (3) the contribution to employment opportunities increased from 11 million in 2014 to 13 million in 2019 , (4) the tourism competitiveness index increased from 70 in 2014 to 30 in 2019, (5) the number of foreign 
tourist arrivals (tourists) increased from 9.4 million in 2014 to 20 million in 2019. As of September 2015, the number of foreign tourists was 8.69 million. Until September 2015, the number of foreign tourists was 8.69 million, and (6) the number of domestic tourist trips increased from 250 million in 2014 to 275 million in 2019 [36].

Characteristics that are commonly found on small islands can be categorized into environmental and socio-economic-cultural aspects. Characteristics related to the environment according to Brookfield in Peuru [23] include: (1) small islands have a narrow catchment area, so that the available freshwater sources are very vulnerable to the influence of seawater instructors, (2) small islands have very open coastal areas (the ratio between the length of the coastline to a relatively large area), so that the environment is very easily influenced by the dynamics of the surrounding waters, (3) species of organisms that live on small islands are generally endemic, and (4) small islands have very limited terrestrial natural resources, both related to natural mineral resources, freshwater and to forestry and agriculture.

The characteristics of the island region that has a specificity, so it requires its treatment, plus the resilience of both physical and non-physical resources that are in palau vulnerable to damage. So if there are ecotourism activities, they must be accompanied by concepts that protect the environment but also help the economic and socio-cultural needs of the surrounding community.

The concept of developing coastal and island tourism areas differs greatly from the management of tourist areas on the mainland, the island region has its peculiarities both in terms of its understanding and characteristics. UNCLOS 1982, Chapter VIII article 121 Paragraph 1 ratified by the Indonesian government through Law No. 17 of 1985 states that the island is a naturally formed terrestrial area surrounded by water and which is above the surface of the tide [23]. The definition that has been recognized by UNCLOS explains that the island is an ecosystem that is surrounded by water and formed naturally.

According to de Haas [11], three small-scale ecotourism concepts must be met, namely environmental sensitivity, socio-cultural viability, and economic viability, all three must be symbiotic to achieve sustainable ecotourism. the results of his research at Niue show that the Niue tourism industry is only sustainable in environmental and socio-cultural aspects, however, due to insufficient tourist visits, it is not economically feasible. Judging from de Hass's research, efforts to make an area into an ecotourism area in a sustainable manner, in its management must be done thoroughly, meaning that it is not enough just to protect the environment, but also must take into account the source of economic income of the surrounding community. By fulfilling the economic needs of the surrounding community, it will foster a sense of responsibility in protecting the tourist environment because it is directly related to survival.

Awareness of environmental conservation based on the surrounding community is very influential on the sustainability and future of the tourist area. Without community support, the ecosystem in tourism areas is very vulnerable to damage, to find out the impact of human activities, especially tourism. [9] studies the environmental impacts of rapid development on the island of Penang, a small, highly urban island off the west coast of Peninsular Malaysia, and points out that many aspects of the island's environment cannot be restored. While nearby Redang Island is also a pristine island, with abundant coral and clear waters and rich in biodiversity. This is a paradise for divers, but because of the incredible increase in the number of tourists in the last decade, it has resulted in the degradation of coral reefs, deforestation, and degradation of genetic 
quality in the environment [9]. One of the community-based conservation measures is to involve the local population as the organizer of the tourism activities, including by becoming a tour guide.

The existence of guides is very important in ecotourism activities because guides play a major role in improving quality and minimizing the influence of tourist activities on the environment. Besides guides, limiting the number of visitors to match the carrying capacity is also very important in conserving the ecotourism area, as a study conducted by Song and Kuwahara [28], in protecting the environment of Minamijima Island, rules forbidding the island exceed the maximum number of tourists allowed every day (one hundred tourists).

Coastal zones are defined as geomorphological areas on both sides of the coast where biotic and abiotic components of the marine and terrestrial environments interact to form complex ecological and economic resource systems, where human populations, both residents and tourists, carry out their activities. Social, recreational and commercial activities (Integrated Coastal Zone Management Protocol in the Mediterranean Sea, 2012). The resources contained in the coastal area make it one of the centers of world civilization, so it is not impossible to see, when there were an earthquake and tsunami disaster in Aceh Province, thousands of people became victims, this proves that the coastal area is the center of human life activities. According to Ozyurt and Ergin [22], Coastal areas have historically been used for human settlements because of the abundance of natural resources needed for survival and development [22].

Mangrove ecosystems are intertidal wetlands in subtropical or tropical coastal areas. This ecosystem has a key role in (i) biogeochemical cycles in tropical estuary ecosystems, (ii) sustainability of coastal marine ecological systems, (iii) support for aquaculture or (iv) stabilization of tropical coastlines [15]. A similar opinion was also conveyed by Gong et.al [13], mangrove ecosystems have a large capacity to hold heavy metals, high copper concentrations have been recorded in mangrove deposits throughout the world now [13].

Strong and sturdy mangrove roots make this ecosystem function to maintain the stability of the coast from the effects of erosion, waves and abrasion, protection of the land (filter), tsunami, hurricanes, seawater intrusion, and the threat of various pollutants and pathogens, ecologically, the mangrove ecosystem functions as a buffer for ecological balance between life on land and sea [32]. Besides mangrove plants also become a source of energy for many marine biota species such as fish, shrimp, shellfish, crabs and various other types of biota, spawning land, rearing (breeding places), animal feed (animal feed) and as a place to live [32]. Economically, the mangrove ecosystem functions as a supplier of products that bring economic benefits to humans, such as providers of recreational facilities, education, aquaculture (marine cultivation) and animal husbandry (honey bees), and providers of products for fuel (charcoal), paper (pulp), construction, household appliances, textiles, leather, food, drinks and medicines (anti-tumor, anti-inflammatory) [25].

The resources contained in mangrove ecosystems will have a positive impact on humans as long as they are properly maintained and managed, but will have a negative impact if irresponsible use and exploitation of mangrove forests continue so that damage to mangrove ecosystems will affect temperature rises, especially in coastal areas. According to Nanlohy et.al [20], this is due to the very low level of knowledge and concern. In the study of Nanlohy et.al [20], the data shows that the percentage level of public knowledge about climate change is very low only at $26.67 \%$ of people in the Kotania bay who know about climate change, while the community of $73.33 \%$ never knew about climate change. 
Seagrasses are plants that float in the sea, which form broad grasslands in shallow coastal waters on all continents except Antarctica [26]. Besides seagrass is also known as one of the most productive marine ecosystems after mangroves and coral reefs [6]. Seagrass beds provide human needs for a long time, for example, Posidonia litter which has been used as a storage area for beds since the 16th century [29]. Seagrass beds contribute to the overall marine ecosystem, both in the ecological and economic fields, including the capacity of seagrass in stabilizing sediments, improving water quality, and its function in the carbon and nutrient cycle, and also serves to provide habitat for various forms of life in waters (Hemming in Nadiarti [19]. In terms of the stability of seagrass ecosystems play a role in the productivity of coral reefs and other fisheries [34], because seagrasses can filter nutrients and sedimentation before burdening coral reefs.

According to Mcleod in Nordlund et.al, [21], the distribution of seagrass populations is currently estimated to range between $177,000-600,000 \mathrm{~km}$, but due to various factors, both due to human activity and an increase in global climate causing a decline in seagrass populations, the estimated rate of decline ranges from $7 \%$ globally [35]. Globally, the loss of seagrass beds between 1879 and 2006 was $27 \mathrm{~km} 2$ [35]. Data from UMCES shows that $58 \%$ of seagrass beds in the world are currently declining, including Indonesia losing around 30-40\% of their seagrass beds [33]. Banten Bay in Indonesia lost about $26 \%$ of its seagrasses caused by the reclamation of ports and industrial areas, and in other parts of Indonesia, Grenyeng Bay and Bojonegara, seagrass degradation was caused by land reclamation for ports [33]. Efforts to conserve seagrass and coastal ecosystems, in general, have been carried out by the government, one of them is by issuing laws and regulations in Indonesia, law 31 of 2004 concerning fisheries and law 27 of 2007 concerning management of coastal areas and small islands, which states that seagrass ecosystems are part of fisheries management [19].

Coral reef ecosystem, is a typical ecosystem located in the tropics, which is formed from the deposition of calcium carbonate $(\mathrm{CaCO} 3)$ produced by reef-forming organisms (hermatypic corals) from the film Cnidaria of the order Scleractina which lives in symbiosis with zooxanthellae and a few additions from calcareous algae and other organisms which secretes carbonates (Benget in Lubis [13]. Coral reef ecosystems are used as tourist sites, around 30\% of the world's coral reefs are valued in the tourism sector, with a total value estimated at nearly US \$ 36 billion, or more than $9 \%$ of the value of coastal tourism in the world's coral reef countries [27]. Indonesia is an archipelago, which is one of the largest coral reef ecosystems. Coral reefs in Indonesia have an area of $50,875 \mathrm{~km} 2$ which is $18 \%$ of the total world coral reefs [8].

The rich ecosystems of the world's coral reefs are being threatened by both natural phenomena and human activities. Climate change is considered the most serious risk for coral reefs worldwide, agricultural pollution threatens about $25 \%$ of the total area of global coral reefs $[8,14]$. Several studies in the Solomon Islands have shown that human population density and market access increases fishing pressure, which in turn is a major driver of threats to farmers' stock and diversity [7].

The presence of ecotourism areas can be both positive and negative. It can positively influence people's living standards, increase income, create new jobs, improve local infrastructure, increase the availability of entertainment facilities, promote local identity, etc. However, tourism also has the potential to cause negative impacts by making living costs and micro crime increase, exacerbating population density and conflict disruption, and changing ecosystems [10]. 
Determination of the status of an area as an ecotourism area is not automatic habitat and diversity within the area is well protected. The closest threat comes from the people who live in and around the ecotourism area. There are often conflicts of interest in the management and development of ecotourism between government policies and the community in terms of meeting various life needs. Minimizing the negative impacts and conflicts of interests above requires a clear positive contribution to environmental preservation, although in practice it is sometimes difficult to achieve. Community feelings play an important role in encouraging community support for the development and conservation of tourism areas [1]. According to Farrell \& Marion, [12], increasing community environmental education and community participation will greatly assist the conservation process in the area around ecotourism, making local communities appreciate the use of natural resources that are not only consumptive, [12]. A similar sentiment was also conveyed by Tsung [30] who understands the support of host citizens for the development of sustainable tourism is an important factor in the success of community-based tourism management and marketing.

\section{Method}

This research is a case study research by direct observation of Reusam Island to collect primary data following the provisions of the experts. Conformity analysis in this study was carried out to get the suitability of field conditions (research results) with ideal conditions set by experts, including Maanema [17] about suitability analysis of coastal ecotourism and marine ecotourism as well as the feasibility of Coastal and Marine ecotourism according to Tuwo [31]. Among the measured ones are 1). Water depth, seabed material, current velocity, water brightness, coast type, land cover and distance to freshwater.

\section{Results and discussion}

Based on geography, Reusam Island is very close to the center of government and the economy in Aceh Jaya Regency. With the Capital District only about $8 \mathrm{~km}$. Reusam Island is bordered directly by the Rigah Bay mainland in the north, west by Lhok Timon Village, in the east by Calang City, the capital city of Aceh Jaya Regency, and in the south by the Indian Ocean. Based on the island's topography, Reusam Island is included in the category of very small islands, with an area of about 22 hectares, which are divided into 4 regions, shrub area has an area of 14.22 $\mathrm{Ha}$, cliffs or rock area has an area of 4.6 ha, in addition to that there is a coral reef area which is a fishing area for those who are interested, has an area of $1.71 \mathrm{ha}$, and the last is a sandy beach area, which is a tourist area, which has an area of $1.4 \mathrm{Ha}$.

In terms of the slope of the cliff, Reusam Island, has no steep or very steep areas, so the height of the cliff is not a threat to tourists. The highest category is somewhat steep, which has an area of about $0.58 \%$ of the island, while the rest is flat and flat, ramps have an area of $21.33 \%$ and flat has an area of $78.09 \%$ of the total island of Reusam. Reusam Island has the same tropical climate as the Aceh region in general with a maximum temperature of $24^{\circ} \mathrm{C}$ to $34^{\circ} \mathrm{C}$ in May 2019 (BMKG, 
2019). Rainfall ranges from $151 \mathrm{~mm}-300 \mathrm{~mm}$, the highest humidity is $90 \%$ with the lowest humidity 60\% in May 2019. Transfers to Reusam Island can be traveled through the Banda Aceh Calang route with a distance of $164 \mathrm{~km}$. while to go to Reusam Island from the mainland must use sea transportation facilities in the form of Board or fishing boats for 10 or 15 minutes, depending on the speed and height of the sea waves at that time.

Tourist visits when there are still docks on the island, based on the results of interviews with the village Geuchik, every Sunday there could reach 500 people visit Reusam Island, but over time with the damage of the pier on the island, and management of the island that is not clear, making tourist interest is greatly decreased, this was proven when Aidil Fitri Eid in 2019, only no more than 50 families visited Reusam Island, this information was obtained from interviews with the village secretary of Lhok Sudu Village.

Tourism facilities on the island of Reusam are generally complete, toilets, Warung Musallah and other supporting facilities, the problem is the problem of management that is not clear, so that makes no one care for facilities that have been built, which causes existing facilities to be damaged by itself. This is influenced by the continued decline in visitors to the island, one of which is because the pier on Reusam Island has been damaged by waves, making Boat and ships unable to land smoothly on the Island.

The Government of Aceh Jaya Regency has developed tourism facilities on the island, this can be seen from the construction of a permanent pier on the mainland to Reusam Island, while on the Island itself has been built musalla, toilets, canteens, and several tourist centers. As for restaurants and permanent supermarkets only available on the mainland. New lodging facilities are available in the City of Aceh Jaya Regency, a distance of $8 \mathrm{Km}$. in the city of calang there are 2 hotels, namely the West Coast Hotel and the Hotel Kana, besides there is also an effendi guesthouse. Meanwhile, the distribution of the benefits of the ecotourism of Reusam Island can be carried out, among others, by making/leaving income from sharia-based ecotourism activities for funds relating to environmental impacts, regional development, local customs, and cultural ceremonies and other social activities. This was strongly supported by the Lhok Timon Village Secretariat as a community representative, he said such activities had been running for 2 years, especially the Lhok Rigaih community was very supportive because Reusam Island was an asset of the village.

The support of the Lhok Timong Village apparatus in developing the eco-tourism area of Reusam Island is in line with existing regulations, one of which is Law No. 6 of 2014 concerning Villages, according to Badaruddin et.al, [4] explains that through Law Number 6 of 2014 In addition to reclaiming villages adat, also provides greater autonomy for villages to be able to manage and develop villages in achieving national development goals, and to achieve prosperous and equitable communities, in addition to the granting of autonomy followed by administration of greater allocation of funds for villages. In another study, Badarudin and Ermansyah [5] said that in the context of implementing the Village Law for rural development, the ability of people to work together, both fellow villagers and with various other stakeholders is a must.

The condition of the resources of Reusam Island to be used as an ecotourism area, is very adequate, this can be seen from several indicators found, including: (1) the depth of the water is 0 to 3 meters, (2) the current speed is $0 \mathrm{~s} / \mathrm{d} 0.12 \mathrm{~m} / \mathrm{sec}$. (3) while the brightness of the waters is at a depth of 7 meters, (4) the type of sandy beach, (5) the cover of low scrubland and the last (6) the distance to the freshwater source which is also available directly on the island of Reusam. 
Table 1. Feasibility of Reusam Island to become Beach Ecotourism

\begin{tabular}{|c|c|c|c|c|c|}
\hline Parameter & Score & $\begin{array}{l}\text { S1 is very } \\
\text { suitable }\end{array}$ & S2 Appropriate & S3 Quete suitable & N Unsuitable \\
\hline $\begin{array}{l}\text { Water depth } \\
\text { (m) }\end{array}$ & 10 & $0-5(18)$ & $>5-10(4)$ & $>10-15(2)$ & $>15(1)$ \\
\hline $\begin{array}{l}\text { Current Speed } \\
\quad(\mathrm{m} / \mathrm{sec})\end{array}$ & 6 & $0-0,17(14)$ & $>0,17-0,34(12)$ & $>0,34-0,51(2)$ & $>0,51(1)$ \\
\hline $\begin{array}{c}\text { Water } \\
\text { Brightness (m) }\end{array}$ & 6 & $>15-20(10)$ & $>10-14(4)$ & $>5-9(2)$ & $\geq 5(1)$ \\
\hline Beach Type & 6 & Sandy (14) & $\begin{array}{l}\text { Sandy little } \\
\text { coral (12) }\end{array}$ & $\begin{array}{l}\text { Slightly steep } \\
\text { rocky sand (10) }\end{array}$ & $\begin{array}{l}\text { Mud, coral, } \\
\text { mangrove, steep } \\
\text { (2) }\end{array}$ \\
\hline Land cover & 6 & Open land (14) & Low scrub (12) & Thick shrub (10) & $\begin{array}{l}\text { Manggrove, } \\
\text { settlement, } \\
\text { slowing (1) }\end{array}$ \\
\hline $\begin{array}{c}\text { Freshwater } \\
\text { Distance }(\mathrm{km})\end{array}$ & 6 & $<0.5(14)$ & $>0.5-1(12)$ & $>1-2(10)$ & $>2(2)$ \\
\hline
\end{tabular}

By juxtaposing the real condition of the existing resources on the island of Reusam into the suitability analysis format of Maanema [17] into coastal ecotourism according to Table 3.1, so that the scores of each of these variables are obtained, namely the depth of waters having a score of 18 , current velocity of 14 , brightness of waters has a score of 2 , the type of sandy beach with a score of 12, land cover 12 and the distance to freshwater has a score of 14. Each score obtained is then multiplied by the weight of each variable, so that the total worth of the beach ecotourism is obtained: $(18 \times 10)+(14 \times 6)+(2 \times 6)+(12 \times 6)+(12 \times 6)$ and $(14 \times 6)=504$. In obtaining the eligibility criteria of Reusam Island to become an ecotourism area the total score of 504 is juxtaposed with Table 4.2 so that it is found that the total score of 502 is in the range of $312-543$ entered into the S2 category or with the appropriate term.

Table 2. Feasibility of coastal ecotourism

\begin{tabular}{ccc}
\hline Category & Skor & Field score \\
\hline S1 (very suitable) & $544-704$ & \\
S2 (as appropriate) & $312-543$ & 502 \\
S3 (quete suitable) & $144-311$ & \\
N (not suitable) & $<144$ & \\
\hline
\end{tabular}

The conformity standard set by Tuwo (2011) shows that it is not much different from the real condition of the island of Reusam, of the fourteen eligibility standards, only one does not meet the requirements, namely the species of the common terarang, in this case, Reusam does not have a 
coral reef even though coral reef conservation activities have been carried out on the island. Whereas in matters such as the types of biota found on the island of Reusam are very diverse, one of which is also a pig, this is evidenced by the discovery of pig traces on the island. The uniqueness of the view on the island of Reusam, is very suitable to be used as an ecotourism area, this is proven by the area of Reusam Island being one of the favorite tourist areas in Aceh Jaya. Meanwhile, the slope and depth factor on Reusam Island is also suitable to be used as a coastal eco-tourism area, which has a slope of $12 \%$ and has a depth of fewer than 10 meters, which is 3 meters.

The parameters of suitability for the elements of wave height and speed of the current also match the determination set by Tuwo [31]. The wave height is at the level of $63 \mathrm{~cm}$ and the current speed is at $12 \mathrm{~cm} / \mathrm{sec}$. Meanwhile for the degree of $\mathrm{pH}$, temperature, and salinity according to the natural levels of seawater, $\mathrm{pH} 7.5$, natural temperature (26) and salinity 32.94 ppt. For more details, see Table 3.3 below:

Table 3. The ecotourism feasibility of Reusam Island

\begin{tabular}{|c|c|c|c|}
\hline No. & Parameter & Criteria & Data \\
\hline 1 & Coral Reef Species & $\begin{array}{l}\text { Very good (> 7), Good (5-6), Medium } \\
\text { (3-4) Not Good }(<4)\end{array}$ & Not good \\
\hline 2 & Coral fish / biota & There are other fauna & $\begin{array}{c}\text { There are other } \\
\text { fauna }\end{array}$ \\
\hline 3 & The uniqueness of the view & there is uniqueness & there is \\
\hline 4 & Slope $(\%)$ & $<15$ & $12 \%$ \\
\hline 5 & Ocean depth (m) & $<10$ & $3 \mathrm{~m}$ \\
\hline 6 & Wave height $(\mathrm{cm})$ & $<70$ & $63 \mathrm{~cm}$ \\
\hline 7 & Current speed $(\mathrm{cm} / \mathrm{sec})$ & $<40$ & $12 \mathrm{~cm} / \mathrm{second}$ \\
\hline 8 & Acidity $(\mathrm{pH})$ & $6,5-8,5$ & 7.5 \\
\hline 9 & Temperature & Natural & 26 \\
\hline 10 & Salinity (ppt) & Experience seawater & 32,94 \\
\hline 11 & Brightness (m) & $>3$ & 7 \\
\hline 12 & Dissolved oxygen (ppm) & $<20$ & $6,9 \mathrm{ppm}$ \\
\hline 13 & Accessibility & Easily accessible & Easily accessible \\
\hline
\end{tabular}

The convenience of beach visitors is one of which is determined by the level of water brightness, in this case, the level of water brightness is around $7 \mathrm{~m}$, the level of dissolved oxygen is around $6.9 \mathrm{ppm}$. The last parameter of Tuwo is acceptability, for the transformation, it is not a problem to go to and from Reusam Island, because there is always a fishing boat that is standby on Reusam Island. 


\section{Conclusions}

Based on the island's topography, Reusam Island is included in the category of very small islands, with an area of about 22 hectares, which are divided into 4 regions, shrub area has an area of $14.22 \mathrm{Ha}$, cliffs or rock area has an area of $4.6 \mathrm{ha}$, in addition to that there is a coral reef area which is a fishing area for those who are interested, has an area of 1.71 ha, and the last is a sandy beach area, which is a tourist area, which has an area of $1.4 \mathrm{Ha}$. Reusam Island resources based on water geomorphological parameters, diversity, marine oceanography physics, water quality, and supporting factors under the feasibility indicators of Tuwo and Maanema have the feasibility of being ecotourism areas, thus Reusam Island can be developed into an ecotourism area

\section{References}

[1] Abang, A, B, Khedif, A, Bohari, Z, Ali, J,K, Ahmad, J, A, Bujang, L, Y, Kibat, S, A. Ecotourism Product Attributes And Tourist Attractions: Uitm Undergraduate Studies. Procedia - Social and Behavioral Sciences 224360 - 367 (2016).

[2] Baksir, B. Pengelolaan Pulau-Pulau Kecil Untuk Pemanfaatan Ekowisata Berkelanjutan Di Kecamatan Morotai Selatan Dan Morotai Selatan Barat Kabupaten Pulau Morotai Provinsi Maluku Utara. Disertasi. Sekolah Pascasarjana Institut Pertanian Bogor (2010).

[3] Adrianto, L. Pembangunan Dan Pengelolaan Pulau-Pulau Kecil yang Berkelanjutan. PKSPL IPB (2004).

[4] Badaruddin \& Ermansyah. Proposing a Model for Law Number 6 of 2014: Evidence from North Sumatra. International Journal of Economic Perspectives 11 188-198 (2017).

[5] Badaruddin,.Revida, E, Ermansyah, Muda, I. Village Governance with Implementation of Law Number 6 of 2014 on the Village and Village Administration. International Journal of Economic Research. 14 (2017).

[6] Blankenhorn, S.U. Seaweed Farming And Artisanal Fisheries In An Indonesian Seagrass Bed Complimentary Or Competitive Usages? Ph.D. Thesis. Universität Bremen, Bremen, Germany. (2007).

[7] Brewer, J.E, Cinner, R. Fisher, A, Green, S.K, Wilson. Market Access, Population Density, And Socioeconomic Development Explain Diversity And Functional Group Biomass Of Coral Reef Fish Assemblages, Global. Environmental change 22. 399-406 (2012).

[8] Burke L, Kathleen R, Mark S dan Allison P. Reef at Risk Revisited in The Coral Triangle. Washington DC: World Resources Institute (2002).

[9] Chan, N.W. Penang Island: Hill Development and Impacts On the Environment. Teh, T.S. (Ed.). Islands in Malaysia: issues and challenges: 139 - 150. Kuala Lumpur: University of Malaya (2000).

[10] Chiappa, G.D,.Atzeni, M,. Ghasemi, V Community-Based Collaborative Tourism Planning In Islands: A Cluster Analysis In The Context Of Costa Smeralda. Journal of Destination Marketing and Management, 20, 2212-571 (2018).

[11] De Haas, H.C. Abstract, Sustainability of Small-Scale Ecotourism: The Case of Niue, South Pacific. Journal of Current Issues in Tourism. Volume 5, 2002-Issue3-4, Dikutip dari http://www.tandfonline.com/doi/abs/10. 1080/13683500 208 667927. pada 30 Mei 2017 (2003).

[12] Farrell, T.A., \& Marion, J. Identifying And Assessing Ecotourism Visitor Impacts At Eight Protected Areas in Costa Rica and Belize. Environmental Conservation,28(3), 15-225 (2001).

[13] Gong, B, Liu, G., Liao, R., Song, J., Zhang, H. 2017. Endophytic Fungus purpureocillium sp. A5 Protect Mangrove Plant Kandelia Can Del Under Copper Stress. Brazilian journal of microbiology 48 530-536530 (2017). 
[14] Kroon, FJ., Schaffelke, B., Bartley, R. Informing Policy to protect coastal coral reefs: Insight from a global review of reducing agricultural pollution to coastal ecosystems. Marine Pollution Bulletin 85. 33-41 (2014).

[15] Kurniawan, A., Hasan, J., Ooi, S, K., Kit, L, W., Leng, L., and Stephane. Understanding Hydrodynamic Flow Characteristics in a Model Mangrove Ecosystem in Singapore. APCBEE Procedia 10. 286 - 291 (2014).

[16] Lubis, H. Pengelolaan Pulau Poncan Gandang Kota Sibolga Untuk Ekowisata. [Disertasi]. Medan: USU, Sekolah Pascasarjana (2013).

[17] Maanema, M. Model Pemanfaatan Pulau-Pulau Kecil. Disertasi. IPB (2003)

[18] Marzouki, M, Frogger, G, and Ballet, J, Ecotourism Versus Mass Tourism. A Comparison of Environmental Impacts Based on Ecological Footprint Analysis. Journal Sustainability, 4. 123-140 (2012).

[19] Nadiarti,. Riani, E, Djuwita, I, Budiharsono, S, Purbayanto, U, Asmus, U. Challenging For Seagrass Management In Indonesia. Journal of Coastal Development. 15 (3) 234-242 (2012).

[20] Nanlohy, H, Bambang, AN, Ambariyanto, Hutabarat, S. Coastal Communities Knowledge Level on Climate Change As a Consideration In Mangrove Ecosystems Management In The Kotania Bay, West Seram Regency. Procedia Environmental Sciences 23. 157 - 163 (2015).

[21] Nordlund, L, M, Jackson, E, M, Nakaoka, M, Villarreal, J, P,.Carretero, P, B,.Creed, J. Seagrass Ecosystem Services - What's Next?. Marine Pollution Bulletin 8 50-536530 (2017).

[22] Ozyurt, G and Ergin. A. 2009. Application Of Sea Level Rises Vulnerability Assessment Model To Selected Coastal Areas Of Turkey. Journal of coastal research ISSN 0749-0258 (2009).

[23] Peuru, G. Pengembangan Ekowisata Di Pulau Lingayan Sebagai Pulau terluar.[Disertasi]. Sekolah Pascasarjana Institut Pertanian Bogor (2012)

[24] Priyono, Y. Pengembangan Kawasan Ekowisata Bukit Tangkiling Berbasis Masyarakat. Jurnal Perspektif Arsitektur. 7 (1) (2012).

[25] Salm, R.V., J.R. Clark \& E. Siirila. Marine and coastal protected area: A Guide For Planners and Managers. Third Edition. International Union for Conservation of Nature and Natural Resources. Gland, Switzerland (2000).

[26] Short, F., Carruthers, T., Dennison, W., Waycott, M. Global Seagrass Distribution and Diversity: a Bioregional Model. J. Exp. Mar. Biol. Ecol. 350, 3-20. http://dx.doi. org/10.1016/j.jembe.2007.06.012 (2007).

[27] Spalding, M, Burke, L,.Wood, S,.Ashpole, J, Hutchison, J, Ermgassen. Mapping The Global Value and Distribution of Coral Reef Tourism. Marine Policy 82.104-113 (2017)

[28] Song, H. and Kuwahara, S. Ecotourism and World Natural Heritage: Its Influence on Islands in Japan. Journal of Marine and Island Cultures 5,36-46 (2016).

[29] Terrados, J., Bodrum, J., Why are Seagrasses Important? - Goods and services provided by Seagrass. pp. 8-10 (2004).

[30] Tsung, H, L. Influence Analysis of Community Resident Support for Sustainable Tourism Development. Tourism Management, 34. 37 - 46 (2013).

[31] Tuwo, A, Pengelolaan Ekowisata Pesisir dan Laut. Surabaya. Brilian International (2011)

[32] Umilia, E, Asbar. 2016. Formulation of Mangrove Ecosystem Management Model Based on EcoMinawisata in The Coastal Sinjai, South Sulawesi. Procedia-Social and Behavioral Sciences 227. $704-711$ (2016).

[33] UNEP. Seagrass in the South China Sea. (2004)

[34] Unsworth, R.K.F. and L.C. Cullen. Recognizing the Necessity for Indo-Pacific Seagrass Conservation. Conserv. Letter. 63-73.(2010).

[35] Waycott, M., Duarte, C.M., Carruthers, T.J.B., Orth, R.J., Dennison, W.C., Olyarnik, S., Calladine, A., Fourqurean, J.W., Heck, K.L., Hughes, A.R., Kendrick, G.A., Kenworthy, W.J., Short, F.T., 
Williams, S.L., Accelerating Loss of Seagrasses Across the Globe Threatens Coastal Ecosystems. Proc. Natl. Acad. Sci.106,12377-12381.9 (2009). Quoted from http://www.pnas.org/content/106/30/1277.full. on October 28, 2017.

[36] Widagdyo, K.G. Analisis Pasar Pariwisata Halal Indonesia. The Journal of Tauhidinomics. 1. (1) 73 80 (2015).

[37] Wunder S. Ecotourism and Economic An Empirical Approach. ecological economics. 2. 465-479 (2000).

[38] Zambrano, AA, Broadbent, E, N, and Duham, W, H. Social and Environmental Effects of Ecotourism in the Osa Peninsula of Costa Rica: the Lapa Rios case. Journal of Ecotourism. 9. (1). $62-83(2010)$. 